\title{
PENGARUH KUALITAS SUMBER DAYA MANUSIA TERHADAP PERKEMBANGAN USAHA PADA KPRI PERTAGUMA KOTA MADIUN
}

\author{
Inggar Ariani Karendra \\ Mahasiswa Prodi Pendidikan Ekonomi FPIPS IKIP PGRI Madiun
}

\begin{abstract}
This study aims (1) to determine the quality of human resources at KPRI "Pertaguma" Madiun City, (2) To determine the development of business in KPRI "Pertaguma", and (3) To determine the effect of the quality of human resources to the business development on KPRI "Pertaguma" Madiun City. The independent variable in this study is the quality of human resources while the dependent variable is business development. Sampling technique using a purposive sampling. The researcher uses purposive sampling technique as sampling technique. Results showed that there is difference between the effect of the quality of human resources to the business development on KPRI Pertaguma Madiun. Free variable at this research is the quality of human resource while variable tied is business development. It can be seen from the calculation of simple linear regression of $\hat{Y}=61.738+0.210 \mathrm{X}$. Where the variable quality of human resources totaled 0.210 shows the influence of the quality of human resources to the business development are positively correlated, meaning that any increase in the quality of human resources $1 \%$ resulted in higher business development at 0.210 units. Based on the results of the analysis can be said to be a significant relationship between quality of human resources and the business development, meaning that there is difference business development of the quality of human resources to the business development on KPRI Pertaguma Madiun.
\end{abstract}

Keys words: Quality of Human Resource, Development of Business

\begin{abstract}
Abstrak: Penelitian ini bertujuan (1) Untuk mengetahui kualitas sumber daya manusia pada KPRI "Pertaguma" Kota Madiun, (2) Untuk mengetahui perkembangan usaha pada KPRI "Pertaguma", dan (3) Untuk mengetahui pengaruh kualitas sumber daya manusia terhadap perkembangan usaha pada KPRI "Pertaguma" Kota Madiun. Variabel bebas pada penelitian ini adalah kualitas sumber daya manusia sedangkan variabel terikat adalah perkembangan usaha. Teknik pengambilan sampel menggunakan teknik purposive sampling. Sedangkan analisis data menggunakan metode statistik regresi linier sederhana dan uji t. Hasil menunjukkan, ada beda pengaruh antara kualitas sumber daya manusia terhadap perkembangan usaha pada KPRI Pertaguma Kota Madiun. Hal ini dapat dilihat dari hasil perhitungan regresi linier sederhana sebesar $\hat{Y}=61,738+0,210 \mathrm{X}$. Dimana variabel kualitas sumber daya manusia yang bernilai sebesar 0,210 menunjukkan besarnya pengaruh kualitas sumber daya manusia terhadap perkembangan usaha yang berkorelasi positif, artinya setiap kenaikan kualitas sumber daya manusia $1 \%$ menyebabkan naiknya perkembangan usaha sebesar 0,210 satuan. Berdasarkan hasil analisis dapat dikatakan antara keduanya ada hubungan signifikan, artinya ada beda pengaruh antara kualitas sumber daya manusia terhadap perkembangan usaha pada KPRI Pertaguma Kota Madiun
\end{abstract}

Kata Kunci: Kualitas Sumber Daya Manusia, Perkembangan Usaha 


\section{PENDAHULUAN}

Pada umumnya orang menganggap koperasi adalah bentuk usaha yang paling ideal dimana anggotanya juga bertindak sebagai produsen, konsumen, dan sebagai pemilik. Dalam konteks Indonesia, koperasi merupakan bentuk usaha yang syah, yang keberadaannya diakui UUD 1945. Secara garis besar tujuan koperasi adalah memajukan kesejahteraan anggotanya, memajukan kesejahteraan masyarakat, dan ikut serta membangun tatanan perekonomian nasional.

Menurut UU No. 17 tahun 2012 pada Bab 1 pasal 1 Koperasi adalah Badan hukum yang didirikan oleh orang perseorangan atau badan hukum Koperasi, dengan pemisahan kekayaan para anggotanya sebagai modal untuk menjalankan usaha, yang memenuhi aspirasi dan kebutuhan bersama di bidang ekonomi, sosial, dan budaya sesuai dengan nilai dan prinsip koperasi.

Berdasarkan UUD No. 17 tahun 2012 Bab II pasal 4 bahwa Koperasi bertujuan "meningkatkan kesejahteraan Anggota pada khususnya dan masyarakat pada umumnya, sekaligus sebagai bagian yang tidak terpisahkan dari tatanan perekonomian nasional yang demokratis dan berkeadilan".

Sedangkan menurut Sonny Sumarsono (2003:7) "koperasi bertujuan memajukan kesejahteraan anggota pada khususnya dan masyarakat pada umumnya serta ikut membangun tatanan perekonomian nasional dalam rangka mewujudkan masyarakat yang maju, adil, dan makmur berdasarkan Pancasila dan UUD 1945".

Menurut Sonny Sumarsono (2003:9) Fungsi koperasi dalam hal ini adalah memberikan jasa kepada anggota dan anggota mengeluarkan biaya untuk menggantinya.

Sedangkan menurut Sudarsono (2010: 80) fungsi dari koperasi adalah alat perjuangan ekonomi untuk mempertinggi kesejahteraan rakyat, alat pendemokrasi nasional, sebagai salah satu urat nadi perekonomian bangsa Indonesia, alat pembinaan insan masyarakat untuk memperkokoh kedudukan ekonomi rakyat.
Dalam melaksanakan perekonomian koperasi, dua aset pokok yang harus dimiliki yakni sumber daya (resources), baik itu sumber daya alam (natural resources), maupun sumber daya manusia (human resources). Kedua sumber daya tersebut sangat penting dalam menentukan keberhasilan dalam mencapai suatu tujuan. Tetapi apabila dipertanyakan mana yang lebih penting diantara kedua sumber tersebut, maka sumber daya manusialah yang paling penting.

Sumber daya manusia merupakan satusatunya sumber daya yang memiliki akal, perasaan, keinginan, keterampilan, pengetahuan, dorongan, daya, dan karsa. Semua potensi sumber daya manusia tersebut berpengaruh terhadap upaya organisasi dalam mencapai tujuan.

Di antara sumber daya yang paling krusial yang dimiliki perusahaan adalah sumber daya manusia. Dikatakan paling krusial karena sumber daya manusia merupakan satu-satunya sumber daya yang sekaligus mampu merencanakan, melaksanakan, dan mengendalikan sumber daya lain.

Menurut Buchari Zainun dalam Akhmad Subekhi (2005:11) suku kata yang terdapat pada sumber daya manusia yaitu "sumber, daya, dan manusia tidak ada satu kata pun yang sulit untuk dipahami. Ketiga kata itu tentu ada artinya dan semuanya dengan mudah dapat dipahami apa artinya. Karena itu tidak perlu dijelaskan masingmasing suku kata tersebut."

Menurut Edi Sutrisno (2010:4) sumber daya manusia harus diartikan sebagai "sumber dari kekuatan yang berasal dari manusia-manusia yang dapat didayagunakan oleh organisasi."

Secara sederhana yang dimaksud dengan sumber daya manusia (SDM) adalah "daya yang bersumber dari manusia. Daya yang bersumber dari manusia ini dapat pula disebut tenaga atau kekuatan atau dengan istilan manpower yang diartikan tenaga kerja"

Pada dasarnya, sumber daya manusia 
adalah suatu sumber daya yang sangat dibutuhkan oleh suatu organisasi. Sebab, sumber daya manusia adalah sumber yang berperan aktif terhadap jalannya suatu organisasi dan proses pengambilan keputusan.

Sumber daya manusia hanya akan diperoleh dari karyawan atau anggota organisasi yang memenuhi ciri-ciri atau karakteristik yaitu memiliki pengetahuan penuh tentang tugas, tanggung jawab, dan wewenang, memiliki pengetahuan yang diperlukan, terkait dengan pelaksanaan tugasnya secara penuh, mampu melaksanakan tugas-tugas yang harus dilakukannya karena mempunyai keahlian, bersikap produktif, inovatif, mau bekerja sama dengan orang lain dan dapat dipercaya.

Sumber daya manusia dapat tetap bertahan karena mereka memiliki kompetensi manajerial yaitu kemampuan untuk merumuskan visi dan strategi perusahaan serta kemampuan untuk memperoleh dan mengarahkan sumber daya-sumber daya lain.

Sumber daya manusia merupakan penerapan pendekatan dimana secara bersama-sama terdapat dua tujuan yang ingin dicapai, yaitu tujuan untuk perusahaan dan tujuan untuk karyawan. Dua kepentingan tujuan tersebut tidak dapat dipisahkan dalam kesatuan kebersamaan yang utuh. Jika kepentingan yang satu dicapai sedangkan yang lain tidak pendekatan sumber daya manusia.

Menurut Sugeng dalam Edi Sutrisno (2010:11) "kualitas sumber daya manusia merupakan pengetahuan, keterampilan, dan kemampuan seseorang yang dapat digunakan untuk menghasilkan layanan profesional."

Sedangkan menurut Masaaki (dalam Kaizen, 1986) dalam Edi Sutrisno (2010:11) "kualitas sumber daya manusia adalah tingkat kemampuan dan kemauan yang dapat ditunjukkan oleh sumber daya manusia”.

Kualitas sumber daya manusia selau tidak akan terlepas dari sebuah kerja profesional. Sehingga sebuah kualitas kerja, haruslah dilibatkan dalam konteks kerja yang merupakan profesi seseorang. Karenanya, tidak mengherankan apabila kualitas sumber daya manusia yang tinggi diharapkan muncul pada kaum profesional.

Kualitas sumber daya manusia ini menyangkut dua aspek yaitu aspek fisik seperti kesehatan dan gizi para pekerja dan non fisik yang menyangkut kemampuan bekerja, berpikir, dan keterampilanketerampilan lainnya.

\section{Klasifikasi Sumber Daya Manusia}

Menurut Ermaya dalam Akhmad Subekhi (2012:13) ada empat macam klasifikasi sumber daya manusia yaitu:

1. Manusia atau orang-orang yang mempunyai kewenangan untuk menempatkan, mengendalikan, dan mengarahkan pencapaian tujuan yang disebut administrator,

2. Manusia atau orang-orang yang mengendalikan dan memimpin usaha agar proses pencapaian tujuan yang dilaksanakan bisa tercapai sesuai rencana disebut manajer,

3. Manusia atau orang-orang yang mempengaruhi syarat tertentu, diangkat secara langsung melaksanakan pekerjaan sesuai dengan bidang tugasnya masing-masing atau jabatan yang dipegangnya.

\section{Prinsip Sumber Daya Manusia}

Menurut Sjahri Mangkuprawira (2002: 15) ada sejumlah prinsip yang harus dipenuhi dalam pendekatan sumber daya manusia yaitu:

1. Karyawan merupakan unsur investasi efektif yang jika dikelola dan dikembangkan dengan baik akan berpengaruh pada imbalan jangka panjang ke dalam perusahaan dalam bentuk produktivitas yang semakin besar.

2. Kebijakan, program, dan pelaksanaan harus diciptakan dengan memuaskan kedua pihak, yaitu untuk ekonomi perusahaan dan kebutuhan kepuasan karyawan.

3. Lingkungan kerja harus diciptakan dimana karyawan terdorong untuk mengembangkan dan memanfaatkan keahliannya 
semaksimal mungkin. Program dan pelaksanaan sumber daya manusia harus dilaksanakan dalam kebutuhan seimbang antara pemenuhan tujuan perusahaan dan karyawan.

Menurut Faustino (2003:26) unsur sumber daya manusia meliputi kemampuankemampuan, sikap, nilai-nilai, kebutuhankebutuhan, dan karakteristik-karakteristik demografisnya. Unsur-unsur sumber daya manusia tersebut sangat dipengaruhi oleh lingkungan sekitarnya seperti norma-norma dan nilai-nilai masyarakat, tingkat pendidikan dan peluang-peluang yang tersedia.

\section{Penilaian Efektivitas Sumber Daya Manusia}

Menurut Soekidjo Notoatmodjo (2003: 128) ada beberapa kriteria yang dapat dijadikan penilaian keefektivitasan sumber daya manusia, yaitu

\section{Kriteria manfaat (benefit criteria)}

Untuk kriteria ini digunakan indikator produktivitas dan kualitas kehidupan kerja.

a) Produktivitas menggunakan indikator:

(1). Peningkatan prestasi kerja

(2). Penurunan absensi karyawan

(3). Penurunan rotasi tenaga kerja

b) Sedangkan untuk indikator kualitas kerja antara lain:

(1). Peningkatan partisipasi kerja

(2). Peningkatan kepuasan kerja

(3). Penurunan stress

(4). Penurunan jumlah kecelakaan kerja

(5). Penurunan jumlah kecelakaan kerja

(6). Penurunan jumlah karyawan sakit

\section{Kriteria biaya (cost criteria)}

Untuk manajemen sumber daya manusia berbagai indikator yang digunakan untuk membiayai suatu kegiatan yang berkaitan dengan pengelolaan sumber daya manusia. Apabila kriteria manfaat pada umumnya untuk diterapkan pada kegiatan personalia secara keseluruhan, maka kriteria biaya adalah lebih spesifik untuk setiap kegiatan. Misalnya kriteria biaya adalah yang sesuai untuk biaya pelatihan, supervisi, pembelian peralatan penanganan, pemindahan sumber daya, dan sebagainya. Setelah kriteria biaya dan kriteria manfaat relevan dan sesuai dengan yang ditentukan, berbagai biaya dan manfaat tersebut dibandingkan. Pembandingan tersebut sebaiknya dilakukan dalam bentuk nilai uang dan rupiah

Kualitas sumber daya koperasi merupakan suatu hal penting dalam perkembangan koperasi secara keseluruhan. Peningkatan manfaat ekonomi yang dirasakan anggota berawal dari meningkatnya pemahaman anggota terhadap hakekat dan manfaat koperasi bagi mereka.

Kualitas sumber daya manusia yang baik di dalam organisasi koperasi dapat menjadi suatu faktor yang berpengaruh dalam mengembangkan kegiatan usaha koperasi. Mengembangkan kegiatan usaha koperasi berarti melakukan upaya-upaya yang bertujuan untuk memberikan perubahan yang lebih baik terhadap usaha yang dijalankan oleh koperasi selama ini.

Organisasi merupakan wadah suatu kegiatan, termasuk kegiatan usaha. Bukan hanya sebagai wadah organisasi juga memberikan kejelasan tentang fungsi, wewenang, dan tanggung jawab setiap orang yang terlibat buah kebutuhan. Dalam kegiatan sebuah usaha. Ketika kegiatan usaha semakin meningkat dan ragamnya semakin luas, maka pembagian dan kejelasan fungsi, tugas dan wewenang menjadi sebuah kebutuhan. Setiap pelaku usaha berharap usaha yang dirintisnya dapat bertahan hidup, tumbuh dan kemudian berkembang.

Menurut J.S. Nimpoena dalam Pandji Anoraga, (2002:178) "pengertian usaha atau bisnis dapat dibedakan dalam pengertian sempit dan pengertian luas. Jika kita berorientasi dalam pengertian sempit maka bisnis tidak lain dari fiksi. Sedangkan dalam arti yang luas, bisnis merupakan usaha yang ter- 
kait erat dengan dunia politik dan juga ekonomi.

Sedangkan perkembangan usaha adalah suatu bentuk usaha kepada usaha itu sendiri agar dapat berkembang menjadi lebih baik lagi dan agar mencapai pada satu titik atau puncak menuju kesuksesan. Perkembangan usaha dilakukan oleh usaha yang sudah mulai terproses dan terlihat ada kemungkinan untuk lebih maju lagi.

Menurut Skinner dalam Pandji Anoraga (2002, 183) agar tetap beroperasi dan memiliki kelangsungan hidup, setiap bisnis harus memiliki tujuan. Ada berbagai tujuan bisnis, namun pada umumnya tujuan bisnis yaitu profit (keuntungan), mempertahankan kelangsungan hidup perusahaan, pertumbuhan perusahaan, tanggung jawab sosial.

Menurut Kasmir (2012:40) cara untuk membuka usaha baru yang lazimnya dilakukan adalah pertama mendirikan usaha baru dimana seseorang memulai usaha dengan mendirikan perusahaan yang baru. Dalam hal ini yang harus dilakukan adalah mengurus segala sesuatu yang berhubungan dengan badan usaha, mulai dari akte notaris sampai pengadilan negeri, kemudian mengurus izinizin yang dibutuhkan. Kedua adalah membeli perusahaan, usaha ini dilakukan dengan cara membeli perusahaan yang sudah ada atau sudah berjalan sebelumnya. Sedangkan yang ketiga adalah Kerjasama manajemen dengan sistem waralaba (franchising). Model ini dikembangkan dengan memakai nama dan manajemen perusahaan lain. Terakhir dengan mengembangkan usaha yang sudah ada artinya, pengusaha melakukan pengembangan atas usaha yang sudah ada sebelumnya, baik pengembangan berupa cabang atau pun penambahan kapasitas yang lebih besar.

Menurut Kasmir (2012: 42-43) untuk menentukan bidang usaha yang akan digeluti tergantung dari 4 faktor yaitu: (1) Minat dan bakat,minat dan bakat sudah ada dan dapat timbul dari dalam diri seseorang, artinya keterkaitan pada suatu bidang sudah tertanam dalam dirinya. (2) Modal, modal secara luas dapat diartikan sebagai uang. Untuk memulai usaha terlebih dahulu diperlukan sejumlah uang. Dalam arti sempit modal dapat diartikan sebagai kemampuan seseorang. (3) Waktu, waktu adalah masa seseorang utuk menikmati hasil dari usahanya. Setiap usaha memiliki masa yang berbeda-beda dalam jangka waktu panjang dan jangka waktu pendek. (4) Laba, faktor yang perlu dipertimbangkan adalah besarnya margin laba yang diinginkan. Di samping itu, dalam hal laba yang perlu dipertimbangkan adalah jangka waktu memperoleh laba tersebut.

\section{Faktor Penyebab Kegagalan Dalam Usaha}

Menurut Kasmir (2012:58) faktorfaktor yang menjadi penyebab kegagalan dalam usaha adalah:

1) Data dan informasi tidak lengkap

Pada saat melakukan perencanaan data dan informasi yang disajikan kurang lengkap sehingga hal-hal yang seharusnya menjadi penilaian tidak ada.

2) Salah perhitungan

Kegagalan dapat pula terjadi karena salah dalam melakukan perhitungan.

3) Pelaksanaan pekerja salah

Para pelaksana usaha di lapangan sangat memegang peranan penting dalam keberhasilan menjalankan usaha tersebut.

4) Kondisi lingkungan

Kegagalan lainnya disebabkan oleh adanya unsur-unsur yang tidak dapat kita kendalikan. Artinya pada saat melakukan penelitian dan pengukuran semuanya sudah selesai dengan tepat dan benar.

5) Unsur sengaja

Kegagalan yang sangat fatal disebabkan oleh adanya faktor kesengajaan untuk berbuat kesalahan artinya karyawan sengaja membuat kesalahan yang tidak sesuai dengan kondisi yang sebenarnya dengan berbagai sebab.

\section{Faktor yang mempengaruhi perkem- bangan usaha koperasi}

Menurut Soedirman (2006) dalam 
(http://edukasi.kompasiana.com/2010/07/29/ koperasi-indo/) faktor yang mempengaruhi perkembangan usaha koperasi meliputi:

1. Faktor internal meliputi:

a) Partisipasi anggota,

b) Solidaritas antar anggota koperasi,

c) Pengurus koperasi yang juga tokoh masyarakat,

d) Skala usaha,

e) Perkembangan modal,

f) Ketrampilan manajerial,

g) Jaringan pasar,

h) Jumlah dan kualitas sumber daya manusia para pengurus dan manajer,

i) Kepemilikan dan pemanfaatan perangkat teknologi produksi dan informasi,

j) Sistem manajemen,

k) Kinerja pengurus

2. Faktor eksternal meliputi:

a) Komitmen pemerintah untuk menempatkan koperasi sebagai soko guru perekonomian nasional,

b) Sistem prasarana, pelayanan, pendidikan dan penyuluhan,

c) Iklim pendukung perkembangan koperasi,

d) Dicabutnya fasilitas tertentu oleh pemerintah,

e) Tingkat harga

\section{METODE PENELITIAN}

Penelitian ini dilakukan di KPRI Pertaguma Jalan Slamet Riyadi No. 81A Kota Madiun. Menurut Moh. Nazir (2003:84) desain penelitian adalah semua proses yang diperlukan dalam perencanaan pelaksanaan penelitian. Dalam penelitian ini menggunakan desain penelitian deskripstif. Menurut Gabriel Amien Silalahi (2003:30) desain deskriptif bertujuan untuk menggambarkan atau memecahkan masalah secara sistematis, faktual, dan akurat mengenai fakta-fakta dan sifat-sifat populasi atau daerah tertentu. Jadi dalam riset dengan desain ini jangan melakukan kesimpulan yang terlalu jauh atas data yang ada, karena tujuan dari desain ini hanya mengumpulkan fakta dan menguraikannya secara menyeluruh dan teliti sesuai dengan persoalan yang akan dipecahkan. Menurut Suharsimi Arikunto (2002:136) metode penelitian adalah cara yang digunakan oleh peneliti dalam mengumpulkan data penelitiannya. Dalam penelitian ini metode penelitian yang digunakan adalah metode kuantitatif. Menurut Sugiyono (2006:14) "metode penelitian kuantitatif adalah metode penelitian yang berlandaskan pada filsafat positivisme, digunakan untuk meneliti pada populasi atau sampel tertentu, pengumpulan data menggunakan insturmen penelitian, analisis data bersifat kuantitatif atau statistik, dengan tujuan untuk menguji hipotesis yang telah ditetapkan"

\section{Variabel Penelitian}

Dalam penelitian ini terdapat dua variabel yang digunakan yaitu Variabel Bebas (X) berupa Kualitas Sumber Daya Manusia dan Variabel Terikat (Y) berupa Perkembangan Usaha.

\section{Teknik Pengumpulan Data}

1. Angket

Dalam penelitian ini teknik angket digunakan untuk melihat bagaimana kualitas sumber daya manusia pada KPRI Pertaguma.

2. Dokumentasi

Dokumen merupakan data yang diperoleh dari penelitian yang berupa dokumen (foto) dan informasi dari masyarakat yang berhubungan dengan obyek penelitian yaitu pengambilan data berupa perkembangan usaha pada KPRI Pertaguma.

\section{Populasi dan Sampel Penelitian}

Populasi dapat diartikan keseluruhan subyek sebagai sarana penelitian. Sedangkan menurut Suharsimi Arikunto (2010:173) "populasi adalah keseluruhan subyek penelitian". Populasi dalam penelitian ini adalah tahun 1963-2014.

Menurut Suharsimi Arikunto (2010: 
174) sampel adalah sebagian atau wakil populasi yang diteliti. Dinamakan penelitian sampel apabila kita bermaksud untuk menggeneralisasikan hasil penelitian sampel. Berdasarkan jumlah populasi maka sampel yang diambil dalam penelitian ini adalah 10 tahun.

Teknik yang digunakan dalam pengambilan sampel untuk penelitian ini adalah teknik purposive sampel. Menurut Gabriel Amin Silalahi (2003:74) purposive sampel adalah peneliti menggunakan pertimbangan sendiri (dengan berbekal pengetahuan yang cukup tentang populasi) untuk memilih anggota-anggota sampel.

\section{Pengujian Hipotesis}

Hipotesis dalam penelitian ini adalah:

Ho = tidak ada pengaruh antara kualitas sumber daya manusia terhadap perkembangan usaha pada KPRI "Pertaguma"

$\mathrm{Ha}=$ ada pengaruh antara kualitas sumber daya manusia terhadap perkembangan usaha pada KPRI "Pertaguma".

Setelah dilakukan penelitian apabila: $r$ hitung $\geq \mathrm{r}$ tabel maka Ha diterima dan Ho ditolak artinya ada pengaruh kualitas sumber daya manusia terhadap perkembangan usaha pada KPRI "Pertaguma” Kota Madiun.

Apabila $r$ hitung $<r$ tabel maka, Ha ditolak dan Ho diterima artinya tidak ada pengaruh kualitas sumber daya manusia terhadap perkembangan usaha pada KPRI "Pertaguma" Kota Madiun.

\section{HASIL PENELITIAN}

\section{Variabel Kualitas Sumber Daya Manusia}

Deskripsi data variabel kualitas sumber daya manusia dengan jumlah $\mathrm{N}$ sebanyak 10 mempunyai deskripsi data sebagai berikut: a) Nilai mean sebesar 49,80; b) Nilai median sebesar 49,50; c) nilai modus sebesar 53; d) Nilai minimum sebesar 46 ; e) Nilai maksimum sebesar 53.

Dari hasil analisis statistik di atas dapat diketahui bahwa hasil kuesioner yang diperoleh nilai di atas rata-rata 49,80 sebanyak 5 pengurus atau $50 \%$. Sedangkan yang berada di bawah nilai rata-rata sebanyak 5 pengurus atau 50\%. Hal ini dapat disimpulkan kualitas sumber daya manusia pada KPRI Pertaguma Kota Madiun adalah cukup baik.

\section{Variabel Perkembangan Usaha}

Deskripsi data variabel perkembangan usaha dengan jumlah $\mathrm{N}$ sebanyak 10 mempunyai deskriptif data sebagai berikut: a) Nilai mean sebesar 633,10; b) Nilai median sebesar 636,50; c) Nilai modus sebesar 404; d) Nilai minimum sebesar 404; e) Nilai maksimum sebesar 772. Dari hasil analisis statistik di atas dapat diketahui bahwa hasil yang diperoleh nilai di atas rata-rata 633,10 sebanyak 5 tahun. Sedangkan yang di bawah nilai rata-rata sebanyak 5 tahun atau 50\%. Hal ini dapat disimpulkan perkembangan usaha pada KPRI Pertaguma Kota Madiun adalah cukup baik.

\section{Hasil Uji Korelasi}

Dari hasil perhitungan uji korelasi diperoleh hasil $r_{\text {hitung }} 0,656$ sedangkan $r_{\text {tabel }}$ dengan $\mathrm{N}=10$, diperoleh $\mathrm{r}$ tabel 0,632 yang berarti bahwa nilai $r_{\text {hitung }}>r_{\text {tabel }}(0,656>0,632)$ yang berarti bahwa Ho ditolak, Ha diterima ada pengaruh positif antara kualitas sumber daya manusia terhadap perkembangan usaha pada KPRI Pertaguma Kota Madiun.

Berdasarkan kriteria atau interpretasi diketahui bahwa untuk uji korelasi sebesar 0,656 termasuk kategori yang kuat. Hal ini mengandung pengertian bahwa perkembangan usaha sangat dipengaruhi oleh kualitas sumber daya manusia pada KPRI Pertaguma Kota Madiun.

\section{Hasil Uji Koefisien Korelasi Signifikan t}

Dari hasil perhitungan atau pengujian yang dilakukan diperoleh persamaan regresi sebagai berikut $\hat{Y}=61,738+0,210 \mathrm{X}$, artinya nilai konstan sebesar 61,738 menunjukkan bahwa perkembangan usaha KPRI Pertaguma 
akan konstan apabila variabel kualitas sumber daya manusia $(\mathrm{X})$ sama dengan nol dengan asumsi faktor-faktor lain tetap atau tidak berubah nilainya. Variabel kualitas sumber daya manusia $(X)$ yang bernilai sebesar 0,210 menunjukkan besarnya pengaruh kualitas sumber daya manusia terhadap perkembangan usaha yang berkorelasi positif, artinya setiap kenaikan kualitas sumber daya manusia $1 \%$ menyebabkan naiknya perkembangan usaha sebesar 0,210 satuan. Dilihat dari nilai positif pada koefisien regresi, maka dapat diketahui bahwa kualitas sumber daya manusia berpengaruh positif terhadap perkembangan usaha pada KPRI Pertaguma Kota Madiun.

Dari data penelitian di atas dilakukan uji hipotesis dengan uji t. Dari hasil perhitungan diperoleh nilai $t_{\text {hitung }}$ sebesar 2,212 sedangkan $t_{\text {tabel }}$ dengan $\mathrm{dk}=10-2=8$ diperoleh $t_{\text {tabel }}$ sebesar 1,859. Berdasarkan nilai $t_{\text {hitung }}$ dan $t_{\text {tabel }}$ tersebut dapat diketahui bahwa nilai $t_{\text {hitung }}=2,212>t_{\text {tabel }}=1,859$ maka dipastikan korelasi antara keduanya signifikan, artinya ada beda pengaruh antara kualitas sumber daya manusia dengan perkembangan usaha pada KPRI Pertaguma Kota Madiun.

\section{Simpulan Hasil Pengujian Hipotesis}

Berdasarkan hasil perhitungan diketahui bahwa untuk persamaan regresi diperoleh hasil $\hat{Y}=61,738+0,210 \mathrm{X}$, nilai konstan sebesar 61,738 menunjukkan bahwa perkembangan usaha KPRI Pertaguma akan konstan apabila variabel kualitas sumber daya manusia (X) sama dengan nol dan variabel kualitas sumber daya manusia $(\mathrm{X})$ yang bernilai sebesar 0,210 menunjukkan besarnya pengaruh kualitas sumber daya manusia terhadap perkembangan usaha yang berkorelasi positif simpulannya adalah apabila kualitas sumber daya manusia meningkat sebanyak $1 \%$ perkembangan usaha akan meningkat pula sebesar $0,210 \%$ apabila faktor lain tetap. Berdasarkan perhitungan uji t diperoleh yaitu $t_{\text {hitung }}=2,212$, selanjutnya dilakukan pengujian nilai korelasi dengan membandingkan nilai $r_{\text {hitung }}$ dan nilai $r_{\text {tabel }}$ agar diketahui tingkat signifikasi korelasi yang terbentuk di antara kedua variabel. Dengan menggunakan jumlah sampel (n) yang diteliti $=10$ dengan $\mathrm{dk}=10-2=8$ dan derajat keyakinan $(\alpha)=$ 0,05 pada tabel $\mathrm{t}$ diperoleh nilai $t_{\text {tabel }}=1,859$. Sesuai hipotesis yang diajukan dapat diperoleh simpulan bahwa ada beda pengaruh antara kualitas sumber daya manusia dengan perkembangan usaha pada KPRI Pertaguma Kota Madiun. Berarti Ho ditolak dan $\mathrm{Ha}$ diterima.

\section{PEMBAHASAN}

1. Kualitas sumber daya manusia

Berdasarkan data angket yang disebarkan kepada pengurus koperasi diperoleh hasil bahwa kualitas sumber daya manusia pada KPRI Pertaguma Kota Madiun dapat dikatakan cukup baik. Hal ini dapat dilihat dari hasil pengujian statistik deskriptif bahwa hasil kuesioner yang diperoleh nilai rata-rata 49,80 sebanyak 5 pengurus atau $50 \%$. Sedangkan yang berada di bawah nilai rata-rata sebanyak 5 pengurus atau $50 \%$. Dari hasil pengujian statistik deskriptif di atas dapat diketahui jumlah total 508 dan standart deviasi sebesar 2,658 dengan jumlah responden sebanyak 10 diketahui statistik deskriptifnya sebagai berikut: a) Nilai mean sebesar 49,80; b) Nilai median sebesar 49,50; c) nilai modus sebesar 53; d) Nilai minimum sebesar 46; e) Nilai maksimum sebesar 53 .

\section{Perkembangan usaha}

Dari data yang diperoleh pada KPRI Pertaguma Kota Madiun dapat diketahui selama 2003-2012 perkembangan usaha mengalami naik turun hal ini dapat dilihat mulai tahun 2003-2004 mengalami kenaikan $12,80 \%$, pada tahun 2005 mengalami kenaikan sebesar 24,07\%, pada tahun 2006 mengalami kenaikan sebesar 
$31,09 \%$, tahun 2007 penurunan sebesar $9,45 \%$ kemudian pada tahun 2008 kenaikan sebesar 21,37\%, pada tahun 2009 kenaikan sebesar $38,18 \%$, pada tahun 2010 kenaikan sebesar $17,80 \%$ dan pada tahun 2011 mengalami kenaikan sebesar $27,12 \%$ dan pada tahun terakhir 2012 mengalami kenaikan sebesar $23,17 \%$, sehingga pada setiap tahun per-kembangan usaha KPRI Pertaguma Madiun mengalami kenaikan dan penurunan.

3. Pengaruh kualitas sumber daya manusia terhadap perkembangan usaha pada KPRI Pertguma Kota Madiun.

Berdasarkan hasil perhitungan diketahui bahwa untuk persamaan regresi diperoleh hasil $\hat{Y}=61,738+0,210 \mathrm{X}$, simpulannya adalah apabila kualitas sumber daya manusia meningkat sebanyak $1 \%$ perkembangan usaha akan meningkat pula sebesar $0,210 \%$ apabila faktor lain tetap. Berdasarkan hasil uji beda pengaruh atau uji t diperoleh hasil yaitu $t_{\text {hitung }}=2,212$, selanjutnya dilakukan pengujian nilai korelasi dengan membandingkan nilai $r_{\text {hitung }}$ dan nilai $r_{\text {tabel }}$ agar diketahui tingkat signifikasi korelasi yang terbentuk di antara kedua variabel. Dengan menggunakan jumlah sampel (n) yang diteliti = 10 dan derajat keyakinan $(\alpha)=0,05$ pada tabel t diperoleh nilai $t_{\text {tabel }}=1,859$. Berdasarkan nilai $t_{\text {hitung }}$ dan $t_{\text {tabel }}$ tersebut dapat diketahui bahwa nilai $t_{\text {hitung }}=2,212>t_{\text {tabel }}=$ 1,859. Dengan demikian Ho ditolak artinya ada beda pengaruh antara kualitas sumber daya manusia terhadap perkembangan usaha pada KPRI Pertaguma Kota Madiun.

\section{PENUTUP}

\section{Simpulan}

Berdasarkan hasil penelitian dan pembahasan maka diperoleh simpulan sebagai berikut:

1. Kualitas sumber daya manusia pada KPRI Pertaguma Kota Madiun dapat dikatakan cukup baik. Hal ini dapat dilihat dari hasil pengujian statistik deskriptif bahwa hasil kuesioner yang diperoleh nilai rata-rata 49,80 sebanyak 5 pengurus atau 50\%. Sedangkan yang berada di bawah nilai rata-rata sebanyak 5 pengurus atau $50 \%$. Dari hasil pengujian statistik deskriptif di atas dapat diketahui jumlah total 508 dan standart deviasi sebesar 2,658 dengan jumlah responden sebanyak 10 diketahui statistik deskriptifnya sebagai berikut: a) Nilai mean sebesar 49,80; b) Nilai median sebesar 49,50; c) nilai modus sebesar 53; d) Nilai minimum sebesar 46; e) Nilai maksimum sebesar 53 .

2. Perkembangan usaha selama 10 tahun berturut-turut mulai tahun 2003 sebesar Rp. 404.000.000, kemudian tahun 2004 sebesar Rp. 498.000.000, yang artinya mengalami kenaikan $12,80 \%$, pada tahun 2005 sebesar Rp. 548.000.000 yang berarti mengalami kenaikan sebesar 24,07\%, pada tahun 2006 sebesar Rp. 621.000 .000 artinya mengalami kenaikan sebesar 31,09\%, tahun 2007 sebesar Rp. 615.000 .000 mengalami penurunan sebesar 9,45\% kemudian pada tahun 2008 sebesar Rp. 650.000.000 mengalami kenaikan sebesar $21,37 \%$, pada tahun 2009 sebesar Rp. 725.000 .000 mengalami kenaikan sebesar $38,18 \%$, pada tahun 2010 sebesar Rp. 731.000.000 mengalami kenaikan sebesar $17,80 \%$ dan pada tahun 2011 sebesar Rp. 772.000.000 mengalami kenaikan sebesar $27,12 \%$ dan pada tahun terakhir 2012 sebesar Rp. 767.000.000 sebesar 23,17\%, sehingga pada setiap tahun perkembangan usaha KPRI Pertaguma Madiun mengalami kenaikan dan penurunan.

3. Berdasarkan hasil uji beda pengaruh atau uji t diperoleh hasil yaitu $t_{\text {hitung }}=2,212$, selanjutnya dilakukan pengujian nilai korelasi dengan membandingkan nilai $r_{\text {hitung }}$ dan nilai $r_{\text {tabel }}$ agar diketahui tingkat signifikasi korelasi yang terbentuk di antara kedua variabel. Dengan meng- 
gunakan jumlah sampel $(\mathrm{n})$ yang diteliti $=$ 10 dan derajat keyakinan $(\alpha)=0,05$ pada tabel $\mathrm{t}$ diperoleh nilai $t_{\text {tabel }}=1,859$. Berdasarkan nilai $t_{\text {hitung }}$ dan $t_{\text {tabel }}$ tersebut dapat diketahui bahwa nilai $t_{\text {hitung }}=2,212>$ $t_{\text {tabel }}=1,859$. Dengan demikian Ho ditolak artinya ada beda pengaruh antara kualitas sumber daya manusia terhadap perkembangan usaha pada KPRI Pertaguma Kota Madiun.

\section{Saran}

Berdasarkan dari simpulan hasil penelitian, maka saran yang dapat peneliti berikan untuk perkembangan usaha KPRI Pertaguma Kota Madiun adalah sebagai berikut:

1. Pengurus Koperasi Pertaguma

Pengurus koperasi diharapkan dapat meningkatkan kepedulian terhadap perkembangan usaha koperasi, dan keaktifan dalam kegiatan koperasi seperti aktif dalam menghadiri RAT, serta berusaha untuk memberikan ide atau saran yang dapat meningkatkan perkembangan usaha koperasi.

2. Karyawan

Karyawan diharapkan selalu meningkatkan pelayanan terhadap anggota koperasi sehingga anggota koperasi merasakan kepuasan dan memiliki rasa setia untuk menggunakan produk di koperasi.

\section{DAFTAR PUSTAKA}

Akhmad Subekhi dan Mohammad Jauhar. 2012. Pengantar Manajemen Sumber Daya Manusia (MSDM). Jakarta: Pustakaraya.

Edi Sutrisno. 2010. Manajemen Sumber Daya Manusia. Jakarta: Kencana.

Gabriel Amien Silalahi. 2003. Metodologi Penelitian dan Studi Kasus. Sidoarjo: Citra Media.
Gomes Faustino Cardoso. 2003. Manajemen Sumber Daya Manusia. Ŷogyakarta: Andi Offset.

Hendar. 2010. Manajemen Perusahaan Koperasi. Jakarta: PT. Gelora Aksara Pratama.

http://resthoe.blogspot.com/2013/02/ perkembangan-usaha-koperasi.html

(diunduh 13 Februari 2013)

http://edukasi.kompasiana.com/2010/07/29/ koperasi-indo/

(diunduh 13 Oktober 2013)

Husein Umar. 2011. Metode Penelitian Untuk Skripsi dan Tesis Bisnis. Jakarta: PT. Raja Grafindo Persada.

Iqbal Hasan. 2004. Analisis Data Penelitian Dengan Statistik. Jakarta: PT. Bumi Aksara.

J. Supranto. 2008. Statistik: Teori dan Aplikasi. Jakarta: Erlangga.

Kasmir. 2012. Kewirausahaan. Jakarta : Raja Grafindo Persada.

Kuswariningsih. 2009. Manajemen Koperasi. IKIP PGRI Madiun.

Moh. Nazir. 2003. Metode Penelitian. Jakarta: Ghalia Indonesia.

Mulyadi Nitisusastro. 2010. Kewirausahaan dan Manajemen Usaha Kecil. Bandung: Alfabeta.

Pandji Anoraga dan Djoko Sudarntoko. 2002. Koperasi, Kewirausahaan, dan Usaha Kecil. Jakarta: PT. Rineka Cipta.

Soekidjo Notoatmodjo. 2003. Pengembangan Sumber Daya Manusia. Jakarta: PT. Rineka Cipta.

Sudarsono dan Edilius. 2010. Koperasi Dalam Teori dan Praktek. Jakarta: PT. Rineka Cipta. 
Suharsimi Arikunto. 2002. Prosedur Penelitian. Jakarta: PT. Rineka Cipta.

Suharsimi Arikunto. 2010. Prosedur Penelitian. Jakarta: PT. Rineka Cipta.

Sumadi Suryabrata. 2006. Metodologi Penelitian. Jakarta: PT. Raja Grafindo Persada.
Tb. Sjafri Mangkuprawira. 2002. Manajemen Sumber Daya Manusia. Jakarta: Ghalia Indonesia.

Uhar Suharsaputra. 2012. Metode Penelitian Kualitatif, Kuantitatif, dan Tindakan. Bandung: PT. Refika Aditama.

Undang-Undang RI No. 17 Tahun 2012 Tentang Perkoperasian. 